Juho-Antti Junno

Sirpa Niinimäki

iD https://orcid.org/0000-0001-9510-5259

Nora Nurminen

iD https://orcid.org/0000-0002-7481-0431

Anniina Kuha

iD https://orcid.org/0000-0002-5898-6074

\title{
Temperature and Humidity in the Base-floors of Three Northern Finnish Churches Containing $17^{\text {th }}-19^{\text {th }}$-century Burials
}

Introduction

The medieval and early modern practice of burying the dead beneath churches has been responsible for preservation of funerary attires and soft tissues in association of several burials still found in old Finnish churches (Paavola 1998; Núñez et al. 2008). Traditionally the mechanism behind the phenomenon is believed to be related to the cessation of decomposition due to a mixture of the coldness in the subarctic regions and low humidity connected to it, while efficient ventilation is considered an additional factor. Particularly remains of those who died during winter were probably exposed to suitable conditions in terms of soft tissue 


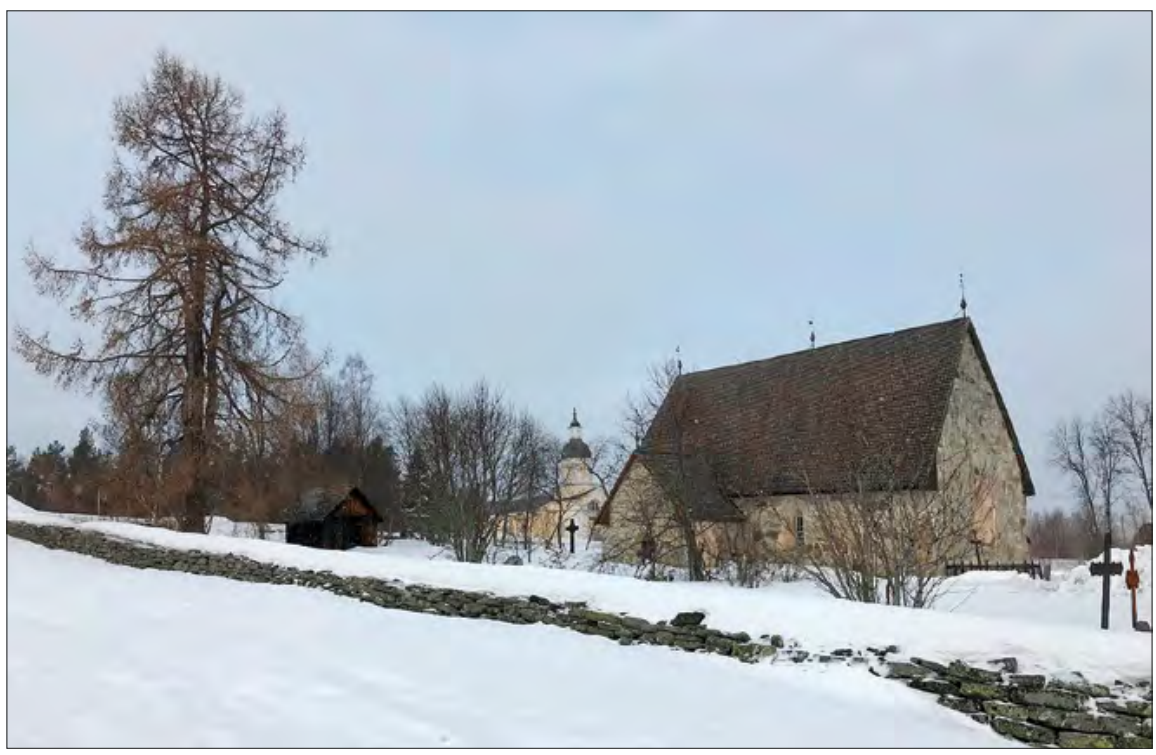

Fig. 1. The old stone church of Keminmaa was built in the mid-I $6^{\text {th }}$ century. (photograph by Tiina Väre).

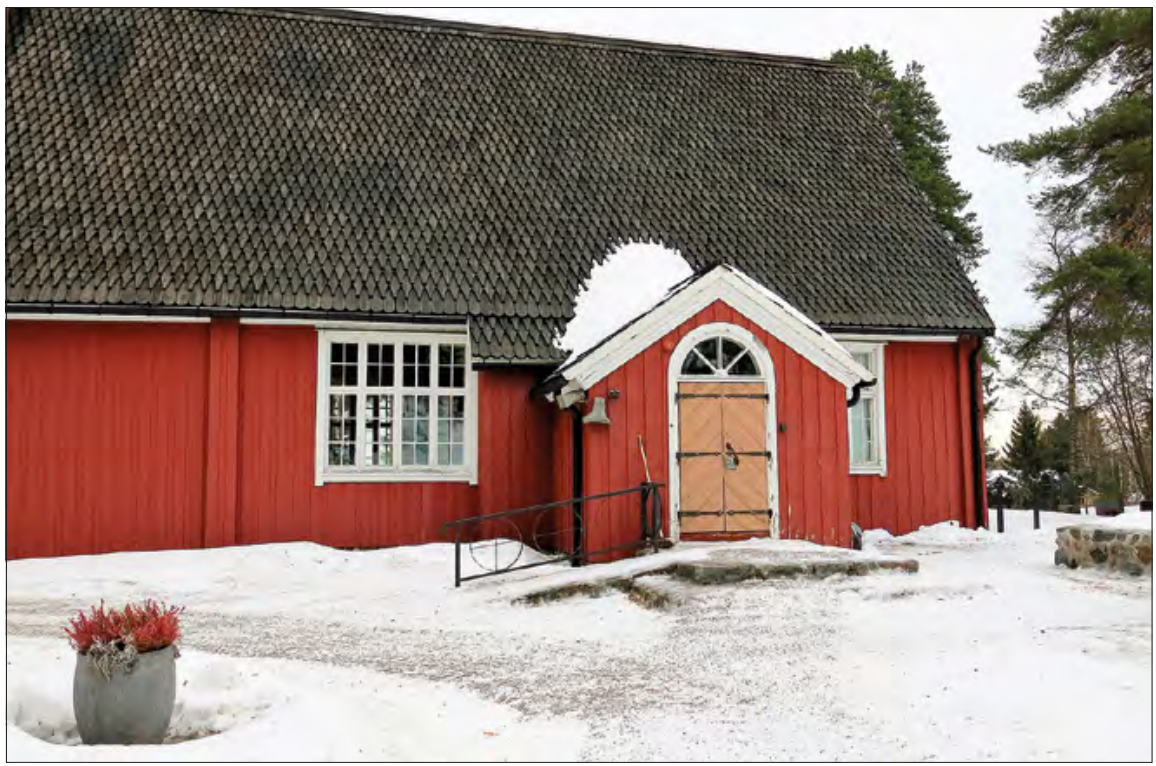

Fig. 2. The old wooden church of Kempele dates to the last decade of the $17^{\text {th }}$ century. It is currently under renovation that will take the preservation of the burials as well as the structures of the church into consideration. (photograph by Titta Kallio-Seppä). 
preservation (Calamnius I868: 20I; Núñez et al. 2008). Generally, the mean winter temperatures particularly in northern Finland remain near zero and the loosely laid stone foundations of some old churches surrounding the coffins allow the air to move removing the moisture from the coffins (Kallinen 1990; Núñez et al. 2008; Aufderheide 2010: 64-65).

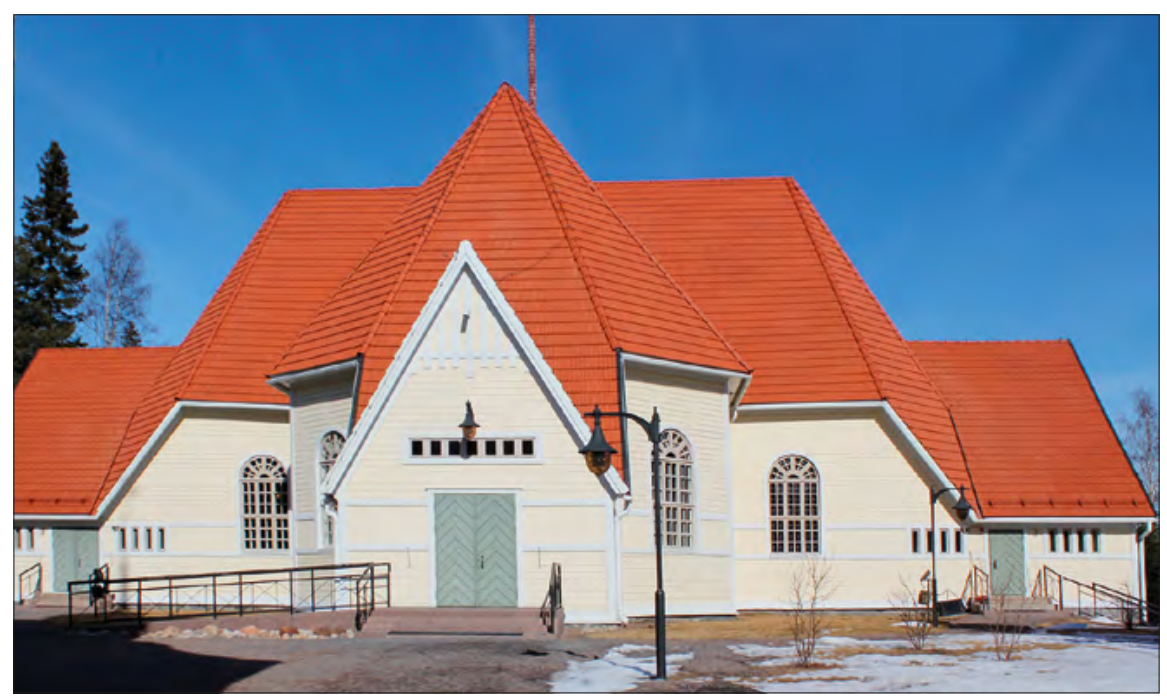

Fig. 3. The church of Haukipudas is still in active use. It was built in the I76os to surround the older church that had located at the same site since the I640s (Vahtola 1980: I7, 78-80). Most of the burials beneath the current church of Haukipudas were originally made under the previous church. (photograph by Titta Kallio-Seppä).

The aim of this paper is to take a look at the conditions in church burials by observing the temperature and humidity conditions in three relevant churches (Fig. I-3) located in three early modern period parishes on the coast of Botnian Bay, Kempele, Keminmaa, and Haukipudas (Fig. 4). Additionally, the significance of the macrofossils found in the coffins will be briefly considered.

Bacterial proliferation significantly slows down at temperatures below $10^{\circ} \mathrm{C}$ and practically ceases at $4{ }^{\circ} \mathrm{C}$ (Laiho 1981: 137; Quigley 2006: 19; Aufderheide 2010: $42-45,48,6 \mathrm{I})$. Globally, there are several examples of cold induced mummification such as the Siberian Pazyryk Burials (Rudenko 1970), the mummified child remains of the Andes (Wilson et al. 2007), the Eskimo remains from Alaska (Zimmerman, Smith 1975) or the famous Ötzi from the Italian Alps (Pernter et al. 2007). Desiccation, as well, causes mummification as enzymes responsible for decomposition require moisture. The lower the temperature, the more insignificant the desiccation required for preservation becomes. While extreme coldness may cause 


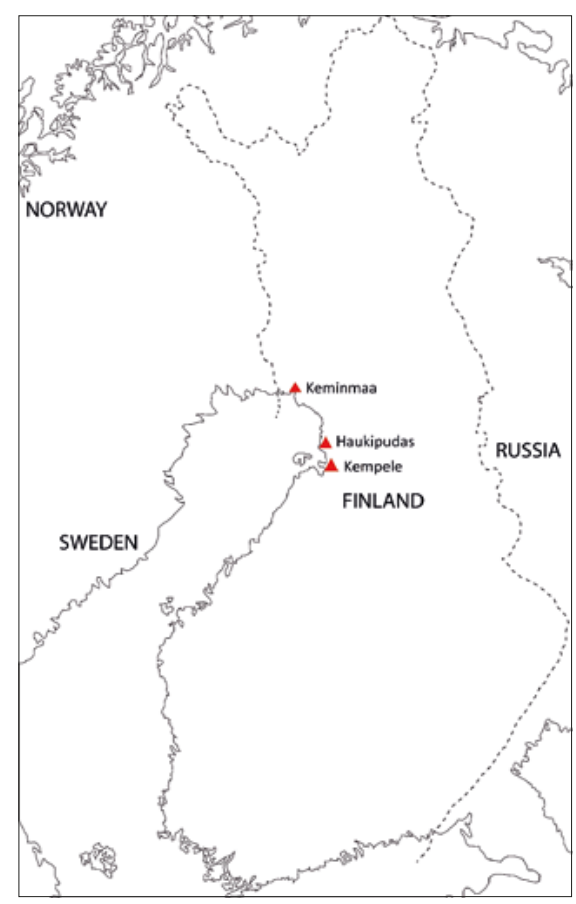
cesses depends on several factors. Changes in the conditions may cause the soft tissue decomposition to cease at any point during the process, which may lead to mummification. External factors such as clothing, the position of the corpse and the type of matrix or internal factors like body composition and size, or the state of health affect the rate of decomposition. For instance, presence of microbes due to perimortem infections may hasten decomposition while bacteria-poor corpses of infants are more prone to mummification (Laiho 1981: 135-137, 139; Fiedler, Graw 2003; Aufderheide 2010: 4I-42; Prahlow 2010: 169-177; Dix, Graham 2000: 13-I4; Janaway et al. 2009: 329).

\section{Under-church-floor burials in the churches of Haukipudas, Keminmaa and Kempele}

All the studied churches were inventoried noninvasively in 1996 and preliminarily re-examined in 2013-20I4. In the old church of Keminmaa (Fig. I) 60 preserved coffins were observed of which 35 were opened and documented with photographs and written descriptions. The base floor of the old church of Kempele (Fig. 2) holds a minimum of is and the church of Haukipudas (Fig. 3 ) ig coffins. At these sites, 
altogether 26 remains have mummified to some extent, and 17 of those belong to children. Preservation varies from almost full mummification to several cases in which mere patches of skin cover parts of the otherwise skeletonized remains, such as skull and fingers. Generally, funerary attire, despite made of organic materials, has preserved better than the human remains and may be found also on the skeletonized remains (29 remains recorded at the studied sites). In each location more are found that are inaccessible without excavations or other invasive research methods (Joona, Ojanlatva 1997a; 1997b; Joona et al. 1997; Kangasvuo, Pöppönen 1997; Marjomaa, Ruonakoski 1997; Ojanlatva 1997; Tikkala 1997; Väre et al. 2014; Lipkin et al. 2020).

The base floors of each church have been visited several times for different purposes, which may have altered the conditions and interfered the process of mummification and preservation. For instance, in Haukipudas, during a renovation in 1908 , the coffins were moved around, opened and the remains within them touched and admired - and sadly, even harmed by the villagers. What is more, when the base floor was cleaned in 2010, unfortunately, researchers visiting the premises noticed that one of the coffins containing well preserved remains was not in its previous place. This raised concerns of the mummified remains having vanished (Ojanlatva 1997; Koskela 1997; Paavola 2012). Alternatively, the coffin may simply have accidentally become coated with the subsoil sands in connection to the cleaning.

The first person known to have been buried under the old church of Keminmaa is the early $17^{\text {th }}$-century vicar, Nikolaus Rungius, who died in 1629 . There still were others before him. In fact, the first burials under churches in Kemi parish dates to the period preceding the old stone church (Koivunen 1997: 45; Paavola 1997; 2009: 24I; Lipkin et al. 2018). The last burial made in the old church during its active use dates to 1784 . From the period between 1698 , when the parish started recording the burials sites, and 1784 , there are records of about 90 burials (Paavola 1997; 1998: 40-43, 77-79; 2009: 242).

Following the construction of a new church in 1799 , the old church, now emptied of furniture, was deployed as a winter depository for the burials. It was no longer considered a permanent gravesite, although removing the coffins in spring was often neglected. As a result, some of them until this day have remained where they were once discarded. While officially prohibited, the practice of burying in the old church was continued at least until 1894 - and according to folklore, as late as the early $20^{\text {th }}$ century (Cajanus 1927: 29-30; Itkonen 1976: 21; Satokangas 1997; Paavola 1997; 1998: 77-78, 86-87; 2009: 242-247).

In Kempele burying under the church began in 1695 and went on for nearly 90 years. Four chamber tombs under the church housed most of the burials. Two of them, located beneath the chancel in the east, were made of stone, while the 
others, located west from the afore mentioned, were of wood. By 1782 , when the floor was opened for a burial for the last time, at least 134 burials had been made beneath it (Hiltunen 1982: 140; Pettersson, Hyvönen 1991: 30; Joona et al. 1997; Paavola 1998: 53-54).

In Haukipudas, two subsequent churches have stood on the same location and more than 200 individuals have been buried beneath them. The burials probably began as soon as the first church was completed in the 1640s, although exactly when, is uncertain. The popularity of the custom of burying under church faded rapidly after the current church was built in 1760s. Only five burials were made under it of which the last in 1765 (Koskela 1997; Paavola 1998: 63-64, 67; 2012).

\section{Observing the conditions in churches and coffins}

It has been generally believed that both the coldness and low humidity contributed to the occurrence of mummification in under-floor graves. During the 1996 inventory in Haukipudas, in August, temperature of $13^{\circ} \mathrm{C}$ was measured a metre under the floor level and although the humidity was not checked up on, a remark was made of it probably being rather low (Ojanlatva 1997). We monitored (Ebron EBI $20 \mathrm{THI})$ the base-floor relative humidity $(\% \mathrm{rH})$ and temperature $\left({ }^{\circ} \mathrm{C}\right)$ twice-daily (4 a.m./p.m.) to conclude about the processes affecting the soft tissue preservation in the old churches of Keminmaa and Kempele, and in the church of Haukipudas. These obtained values were compared to the temporally corresponding humidity and temperature observations collected from the nearest weather stations using the open data source of Finnish Meteorological Institute to assess how the base floor conditions are afflicted by the changes in outside weather conditions. The weather stations in question were Kemi-Tornio airport, Oulunsalo airport, and Oulu Vihreäsaari, respectively.

In Keminmaa the complete data covers the period of 16. Sep. 2013 to 31. Jan. 2016, in Kempele, 27. June 2013 to 29. Sep. 2014, and in Haukipudas I. April 2014 to 30. June 20I5, apart from some missing values in the data from the weather stations. In Keminmaa and Kempele the year-long periods chosen for closer observation were temporally corresponding - from the beginning of October 2013 to the end of April 2014. Due to different measuring periods it was impossible to get data of a full year from the same period from all the churches. The data logging in Haukipudas began a half year later than the selected year-long observation period in the other churches.

The minimum and maximum temperatures as well as monthly averages in the base-floor conditions were observed. Moreover, independent Samples T-Test ( $95 \%$ level of confidence; IBM SPSS 22) were utilized to compare the conditions in the churches and to find out how the relative humidity differed between winter 
(October to March) and summer months (April to September). Additionally, we observed the periods the temperature had dropped below $4^{\circ} \mathrm{C}$ and $10^{\circ} \mathrm{C}$ to assess the proportion of time the conditions are hostile to the bacteria causing decomposition.

In addition to the temperature and humidity, we made observations concerning other factors significant in terms of preservation and decay. These include the funerary attire and furnishing of the coffin as various qualities of fabrics as well as plants utilized for the purpose sometimes induce preservation. Additionally, the surrounding conditions and mummification stage correspond to the found insect remains, as each species specialize in certain habitats limited for example by temperature and nutrition. By observing which insect species that participate in postmortem processes are most commonly found in association with the burials, it may be possible to shed light on the issue of whether mummification occurred mainly during the colder months. Insects are used in forensic research to determine, inter alia, post-mortem intervals (Amendt et al. 2004). Insects are limited to certain living conditions and their existence or absence tells about mummification. The insect population beneath church floors was studied by sporadic sample taking. A more thorough sampling methods to maintain a general view could not be used due to the temporal and practical restrictions. Accurate analysis is not possible because we do not know contemporary local insect population (Prado e Castro et al. 2012; Grassberger, Frank 2004; Grassberger, Reiter 2002: 18I), and modern sampling has been sporadic.

\section{Representativeness of the logged data}

The logged data may offer clues to the conditions under which mummification occurred. Nevertheless, it mainly reveals how the human remains in our churches are currently stored and not necessarily the conditions under which mummification took place. Firstly, the climate during the period under which burials were made beneath church was not similar to that today. Dendroclimatological research based on tree-ring growth is used in defining past climate variables for smaller localities but also for larger regions. The tree-ring data from older trees can give centennial or even millennial old valuable information on past climate variables from the times when the weather was not observed or information on it recorded with any instruments (Helama et al. 2005). For Finnish Lapland a more than 7600 year-long ring-width chronology has been put together by sampling living and subfossil Scots pines (Pinus sylvestris L.) (Eronen et al. 2002; Helama et al. 2002). This chronology reveals that a long warmer period (Medieval Warm Period, MWP) prevailed in northern Finland between the $\mathrm{IO}^{\text {th }}$ and the $\mathrm{I}^{\mathrm{th}}$ centuries. The warm period ended in a cooler period known as the Little Ice Age (LIA) that lasted until the beginning of the $20^{\text {th }}$ century. In the Lapland chronology, the 
coolest 250-year period occurred in 160I-1850. The Little Ice Age did not mean that the weather was always colder, and the period contained also warmer decades (Helama et al. 2009: 452; Mielikäinen et al. 2012: 38-39). Tree-ring based research on summer temperatures in Scandinavia has shown that during the $17^{\text {th }}$ and $18^{\text {th }}$ centuries the warming was most pronounced around 1660 and 1780 . Cooling on the other hand was most intense during the first half of the $17^{\text {th }}$ century with the coldest summer in 1633 (Büntgen et al. 2011: 3-4). During the coldest period of the $17^{\text {th }}$ century, the summers were approximately two degrees cooler compared to the last 2000 years average (Büntgen et al. 20II; Mielikäinen et al. 20I2: 48).

Additionally, it is good to bear in mind that modern renovations in the churches may have altered their conditions. The interior of the wooden old church of Kempele is currently heated during special occasions, but otherwise the temperature has been stabilized at ${ }_{12}{ }^{\circ} \mathrm{C}$. Currently, its soil-embedded foundation is air-tight. Yet, if the weather suddenly gets drastically colder, the inside temperature may temporarily drop near zero degrees (Raappana 2017). The church of Haukipudas is still in active service and normally kept warm during winter (Vahtola 1980: 192, 194). The dry-laid foundation is not air-tight, but has see-through holes between the stones. However, the floor at Haukipudas is insulated. The old church of Keminmaa has walls of stone and is kept cold, the foundation is air-tight and embedded into the soil. It, however, probably has remained the most unchanged of the three although it, too, was thoroughly renovated on few occasions during the $20^{\text {th }}$ century and after the church burial practice formally ended its crypt has been filled up with sandy soil (Núñez et al. 2008), which may have altered humidity. Additionally, as it no longer is in active use: during the church burial period, even the body heat generated by the parishioners, may have contributed to the underfloor conditions. However, the measurements made there may be the most representative in terms of concluding about the original mummification processes, while the contrast to the other churches may reveal the effect of the heating systems installed in Kempele and Haukipudas during the $20^{\text {th }}$ century.

\section{Some preliminary observations}

\section{Conditions under the floors}

The conditions in each church are different (Tab. I). Nevertheless, all buildings even out the effects of the daily changes observed in outdoor conditions and protect the base floors from the weather extremes (Fig. 5-8). Of the tree churches, Keminmaa is the coldest with less short-term variation in temperature ( $5 \mathrm{a}, 7 \mathrm{a})$ while Kempele is the warmest (Fig. 5b, 7a; Tab. I). The values measured in Haukipudas generally fall between those of the other churches (Fig. 5c, 7a). This is substantiated by the yearly average temperatures in each church (Keminmaa $5.0^{\circ} \mathrm{C}$, Kempele $10.7^{\circ} \mathrm{C}$, 
Tab. 1. Temperature and humidity during winter and summer. As the mummifications likely took place during colder months, the winter months and the summer months were looked at separately.

\begin{tabular}{|c|c|c|c|c|}
\hline & Max & Min & Mo & Md \\
\hline \multicolumn{5}{|l|}{ Temperature ${ }^{\circ} \mathrm{C}$} \\
\hline Church Keminmaa (Oct-Mar 2013-I4, 2014-15) & 9.2 & -9.0 & 2.0 & 0.7 \\
\hline Church Kempele (Oct-Mar 2013-14) & 14.2 & -8.3 & 6.9 & 6.4 \\
\hline Church Haukipudas (Oct-Mar 2014-15) & 10.3 & -4.8 & 3.6 & 3.7 \\
\hline Kemi-Tornio airport (Oct-Mar 2013-14, 2014-15) & 10.7 & -26.6 & 0.6 & -0.9 \\
\hline Oulunsalo airport (Oct-Mar 2013-14) & 11.6 & -25.1 & 0.1 & 0.1 \\
\hline Vihreäsaari, Oulu (Oct-Mar 20I4-I5) & 10.3 & -20.9 & 0.5 & 0.0 \\
\hline \multicolumn{5}{|l|}{ Humidity \%rH } \\
\hline Church Keminmaa (Oct-Mar 2013-I4, 2014-I5) & 93.5 & 80.9 & 92.9 & 92.2 \\
\hline Church Kempele (Oct-Mar 2013-14) & 71.4 & 40.7 & 65.7 & 61.1 \\
\hline Church Haukipudas (Oct-Mar 2014-15) & 81.5 & 51.4 & 76.2 & 72.6 \\
\hline Kemi-Tornio airport (Oct-Mar 2013-14, 2014-15) & 100.0 & 34.0 & 100.0 & 95.0 \\
\hline Oulunsalo airport (Oct-Mar 2013-I4) & 100.0 & 46.0 & 100.0 & 94.0 \\
\hline \multirow[t]{2}{*}{ Vihreäsaari, Oulu (Oct-Mar 20I4-I5) } & 100.0 & 40.0 & 91.0 & 90.0 \\
\hline & Max & Min & Mo & Md \\
\hline \multicolumn{5}{|l|}{ Temperature ${ }^{\circ} \mathrm{C}$} \\
\hline Church Keminmaa (Apr-Sep 2014, 2015) & 16.1 & 0.5 & 12.4 & 10.4 \\
\hline Church Kempele (Apr - Sep 2014) & 23.4 & 4.8 & 17.2 & 16.2 \\
\hline Church Haukipudas (Apr-Sep 20I4) & 18.5 & 1.3 & 10.5 & 12.1 \\
\hline Kemi-Tornio airport (Apr-Sep 2014, 2015) & 28.8 & -10.7 & 15.4 & 11.2 \\
\hline Oulunsalo airport (Apr-Sep 2014) & 28.5 & -9.6 & 4.1 & 11.2 \\
\hline Vihreäsaari, Oulu (Apr-Sep 20ı4) & 27.3 & -9.7 & 14.3 & 11.9 \\
\hline \multicolumn{5}{|l|}{ Humidity \%rH } \\
\hline Church Keminmaa (Apr-Sep 2014, 2015) & 94.4 & 87.8 & 92.9 & 92.2 \\
\hline Church Kempele (Apr-Sep 2014) & 72.1 & 44.2 & 66.4 & 60.9 \\
\hline Church Haukipudas (Apr-Sep 20I4) & 89.0 & 53.3 & 83.5 & 77.8 \\
\hline Kemi-Tornio airport (Apr-Sep 2014, 2015) & 100.0 & 28.0 & 100.0 & 81.0 \\
\hline Oulunsalo airport (Apr-Sep 2014) & 100.0 & 24.0 & 100.0 & 77.0 \\
\hline Vihreäsaari, Oulu (Apr-Sep 20ı4) & 99.0 & 28.0 & 81.0 & 79.0 \\
\hline
\end{tabular}


Tiina Väre, Annemari Tranberg, Sanna Lipkin, Titta Kallio-Seppä, Lauri Väre...
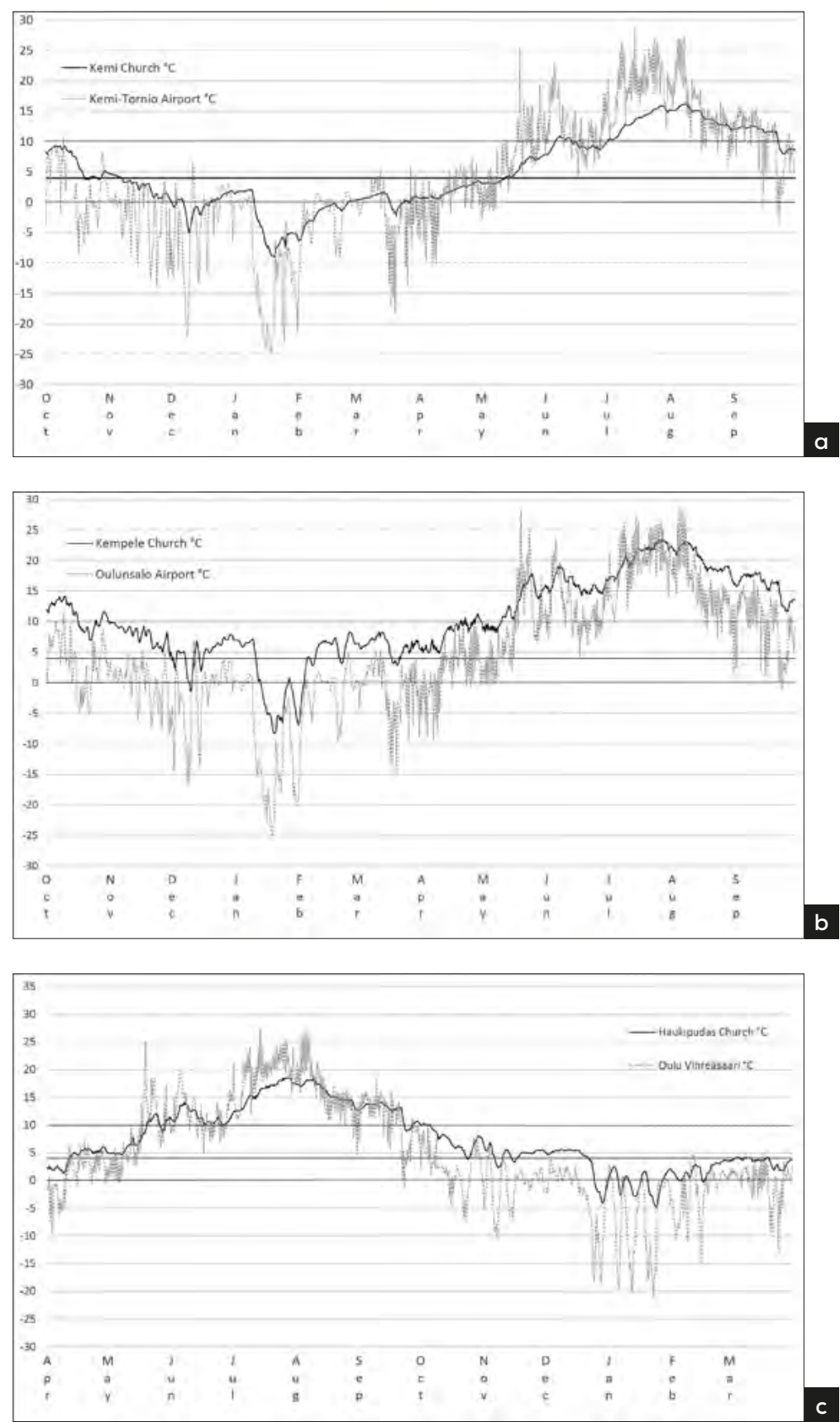

Fig. 5 (a-c). Temperatures in the old churches of Keminmaa and Kempele and in the church of Haukipudas. 
Haukipudas $7.4^{\circ} \mathrm{C}$ ). Only when the outdoor temperatures drop very low, the temperatures in the base-floor of old church of Kempele begin to resemble those in the old church of Keminmaa.

The temperatures of all churches follow a pretty similar pattern. Interestingly, this is despite the measurements in Haukipudas are not temporally corresponding with those of the other churches. At Haukipudas the winter temperatures used in the comparison of temperature and later the humidity values represent the winter 2014-2015, while the spring and summer temperatures, beginning from April, were measured during 20I4. The temperatures during the winter do not fit the overall pattern that otherwise runs neatly between the two other churches (Fig. 7a). This may be because the mid-winter from November 2014 to January 2015 was generally slightly warmer than the corresponding period a year earlier, which is when the measurements in Keminmaa and Kempele were made.

As mentioned, the bacterial proliferation essentially ceases when temperature drops to $4^{\circ} \mathrm{C}$ or below (Laiho 198I: 137 ). While looking at the monthly average temperatures from October to April, the outdoor temperatures stay lower than that. This is reflected to the base floor of the old church of Keminmaa so that the monthly mean temperature does not exceed this point between November and April (Fig. 8a), while in Haukipudas the same is true between the months of December to March (Fig. 8b). In Kempele, on the other hand, only the average temperature of January would be cold enough to cease the decomposition (Fig. 8a).

Nevertheless, even in temperatures of $10^{\circ} \mathrm{C}$ and below the decomposition begins to significantly slow down (Quigley 2006: 19). In the old church of Keminmaa, the monthly averages remained lower than this from October to June, in Kempele from November to April (Fig. 8a), and in Haukipudas October to May (Fig. 8b). In the old church of Keminmaa church, during the year-long observation period the temperature remained at $10^{\circ} \mathrm{C}$ or below in $75.1 \%$ of the twice-daily loggings and at $4^{\circ} \mathrm{C}$ or below in $52.6 \%$ of them, while the temperature dropped below the freezing point in $18.9 \%$ of the measurement points. In Kempele church the corresponding proportions were $53.6 \%, 11.4 \%$, and $5.6 \%$, and in Haukipudas, $7 \mathrm{I} .2 \%, 30.8 \%$, and $7.6 \%$ respectively (Tab. 2 ).

The churches are different in terms of the relative humidity in their base floors, as well (Fig. 6, 7b). In general, however, it is safe to say that each of them appears surprisingly humid in consideration that they contain mummified remains. Beneath the old church of Keminmaa the relative humidity during the observation period between October 2013 and September 2014 on average remained very high at 91.2\%, while in the driest Kempele church it was only 59.5\% rH. Haukipudas, with \%rH of 73.5 , again falls between the two other churches. The variance in the humidity result is likely tied to the differing structural compositions of the churches: the most humid old church of Keminmaa is made of stone, the base-floor of the church 
Tab. 2. The proportions of measurement points when the conditions remained hostile to the bacteria responsible for decomposition in each church during the selected yearlong observation periods.

\begin{tabular}{|c|c|c|}
\hline \multicolumn{3}{|c|}{$1^{\text {st }}$ October $2013-30^{\text {th }}$ September 2014} \\
\hline & Kemi Church & Kempele Church \\
\hline Total of measurement points & 730.0 & 730.0 \\
\hline Temperature $\leq 10^{\circ} \mathrm{C}$ & 548.0 & 391.0 \\
\hline$\% \leq 10^{\circ} \mathrm{C}$ & 75.1 & 53.6 \\
\hline Temperature $\leq 4^{\circ} \mathrm{C}$ & 384.0 & 83.0 \\
\hline$\% \leq 4^{\circ} \mathrm{C}$ & 52.6 & 11.4 \\
\hline Temperature $\leq 0^{\circ} \mathrm{C}$ & 138.0 & 41.0 \\
\hline$\% \leq 0^{\circ} \mathrm{C}$ & 18.9 & 5.6 \\
\hline \multicolumn{3}{|c|}{$1^{\text {st }}$ April 2014- 31 $1^{\text {st }}$ March 2015} \\
\hline & \multicolumn{2}{|c|}{ Haukipudas Church } \\
\hline Total of measurement points & \multicolumn{2}{|c|}{730.0} \\
\hline Temperature $\leq 10^{\circ} \mathrm{C}$ & \multicolumn{2}{|c|}{520.0} \\
\hline$\% \leq 10^{\circ} \mathrm{C}$ & \multicolumn{2}{|c|}{71.2} \\
\hline Temperature $\leq 4^{\circ} \mathrm{C}$ & \multicolumn{2}{|c|}{225.0} \\
\hline$\% \leq 4^{\circ} \mathrm{C}$ & \multicolumn{2}{|c|}{30.8} \\
\hline Temperature $\leq 0^{\circ} \mathrm{C}$ & \multicolumn{2}{|c|}{52.0} \\
\hline$\% \leq 0^{\circ} \mathrm{C}$ & \multicolumn{2}{|c|}{7.1} \\
\hline
\end{tabular}

of Haukipudas is enclosed by a foundation of large loosely laid stones allowing air movement but also influence of weather conditions, and the base-floor of the old church of Kempele is rather tightly insulated. These structural differences must be significant in terms of the differences in base-floor humidity.

During winter, on average, the relative humidity in the old church of Keminmaa is actually very similar to the average outdoors and even exceeds it (Tab.3). The base floor is sheltered from the extreme humidity of outdoors, while on the other hand, it remains rather moist even when the weather gets drier. In the churches of Kempele and Haukipudas, the humidity varies much more rapidly according to the outdoor conditions although, again, the extremes are avoided. While dry in comparison to the Keminmaa church and the outdoor humidity, both the other churches still are rather humid in comparison to normal insulated and heated indoor conditions in Finland (Tab. I, 3; Fig. 6, 7b). 
The weather stations recorded notable daily variation in relative humidity, but this would not reflect in the base floor conditions in Keminmaa church where the humidity remains rather stable during the whole observation period (Fig. 6a). Nevertheless, slight but statistically significant difference in relative humidity can been observed between winter (October-March) and summer months (April-September). This is true not only in the Keminmaa church but also in the two other churches, although the difference is not as clear as it is between the winter and summer measurements at the weather stations (Tab.3).

Some of the differences between the churches presented above may be related to the indoor heating (the base floor is not heated) in Kempele and Haukipudas churches. It may even be responsible for the less humid air in both locations although probably also the different building materials play a role in this. Only in Haukipudas church, where the heating is permanently on during the winter months, the air is dryer during the winter than summer.

As the conditions in the churches are not very similar, one interpretation may be that neither the humidity nor temperature explain the phenomenon alone, but ventilation could be an important factor as well. Unfortunately, monitoring the ventilation in the churches' premises was not performed during the measurements. Nevertheless, if ventilation is ineffective, the moisture that is locked in humid air will condense on wooden structures - and presumably other organic materials such as mummified remains. It is likely that some of the current structures that may be harmful in terms of excess humidity and proper ventilation are a result of later renovations, sinking of the buildings and simultaneous accumulation of cultural layers around them. As these probably were not causing issues during the period of church burials, we may presume that the ventilation at that time was much more efficient.

Tab. 3. Comparison between the average summer and winter temperatures and relative humidity averages throughout the measuring periods.

\begin{tabular}{|c|c|c|c|c|c|c|}
\hline & $\begin{array}{l}\text { Keminmaa } \\
\text { Church }\end{array}$ & $\begin{array}{l}\text { Kempele } \\
\text { Church }\end{array}$ & $\begin{array}{l}\text { Haukipudas } \\
\text { Church }\end{array}$ & $\begin{array}{c}\text { Kemi-Tornio } \\
\text { Airport }\end{array}$ & $\begin{array}{c}\text { Oulunsalo } \\
\text { Airport }\end{array}$ & $\begin{array}{c}\text { Vihreäsaari } \\
\text { Oulu }\end{array}$ \\
\hline \%rH Oct-Mar & 92.1 (sD 1.3) & $63.7(\mathrm{sD} 6.7)$ & $70.8(\mathrm{sD} 6.0)$ & 90.8 (sD 10.3) & $91.2(\mathrm{sD} 10.4)$ & 87.7 (sD 9.5) \\
\hline Oct-Mar N & 974 & 364 & 364 & 960 & 364 & 364 \\
\hline$\%$ rH Apr-Sep & 91.9 (sD 1.5) & $59.2(\mathrm{sD} 8.2)$ & $76.3(\mathrm{sD} 7.6)$ & $78.1(\mathrm{sD} 17.9)$ & $74.5(\mathrm{sD} 20.1)$ & $76.9(\mathrm{sD} 13.7)$ \\
\hline Apr-Sep N & 761 & 557 & 547 & 758 & 558 & 547 \\
\hline $\mathrm{t}$ & -3.872 & 9.222 & 12.123 & -17.516 & -13.928 & -14.061 \\
\hline $\mathrm{df}$ & 1509.318 & 878.484 & 879.769 & 1143.709 & 893.285 & 907.470 \\
\hline Sig. (2-tailed) & .000 & .000 & .000 & .000 & .000 & .000 \\
\hline
\end{tabular}


Tiina Väre, Annemari Tranberg, Sanna Lipkin, Titta Kallio-Seppä, Lauri Väre...
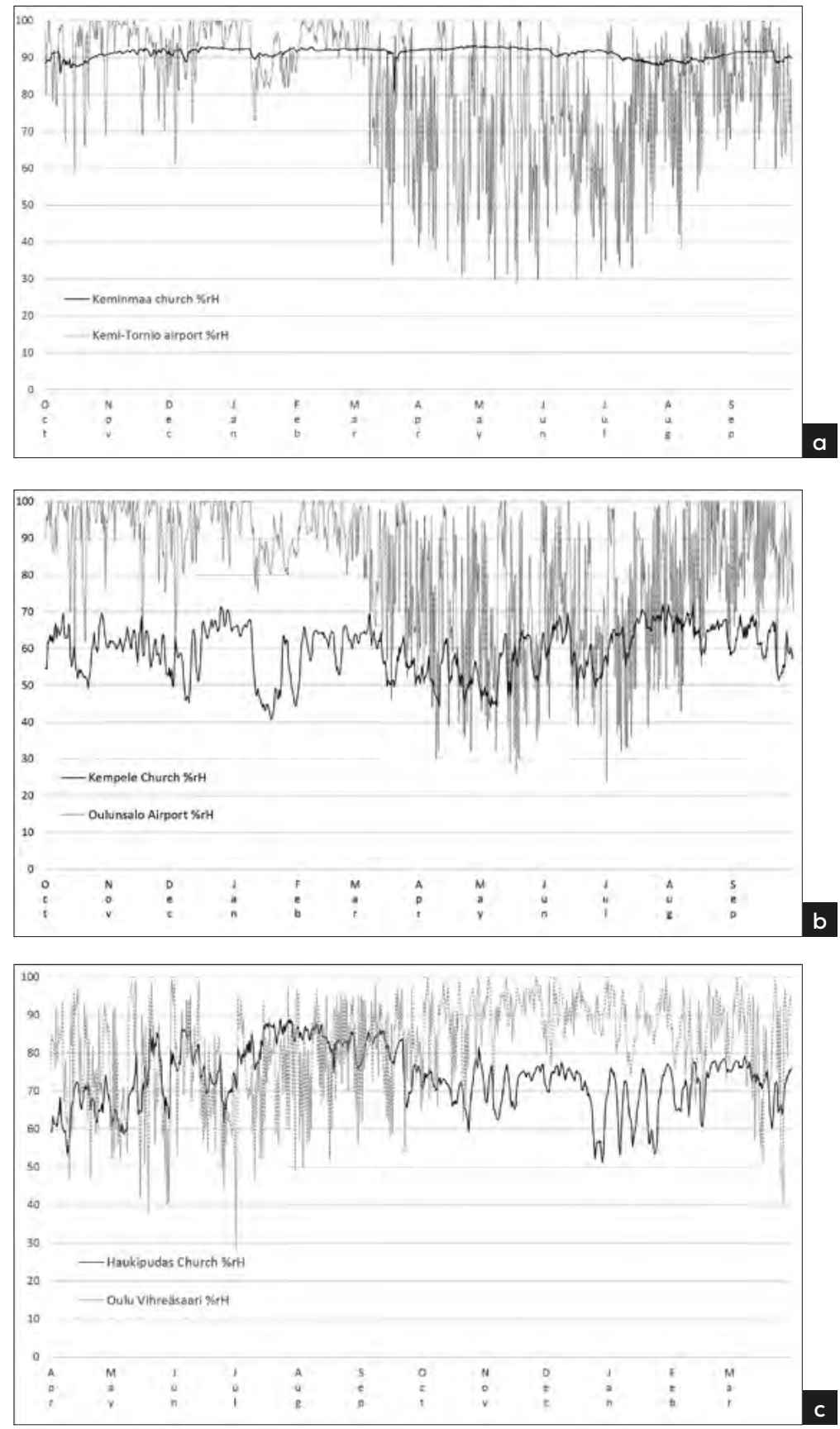

Fig. 6 (a-c). Humidity in the old churches of Keminmaa and Kempele and in the church of Haukipudas. 

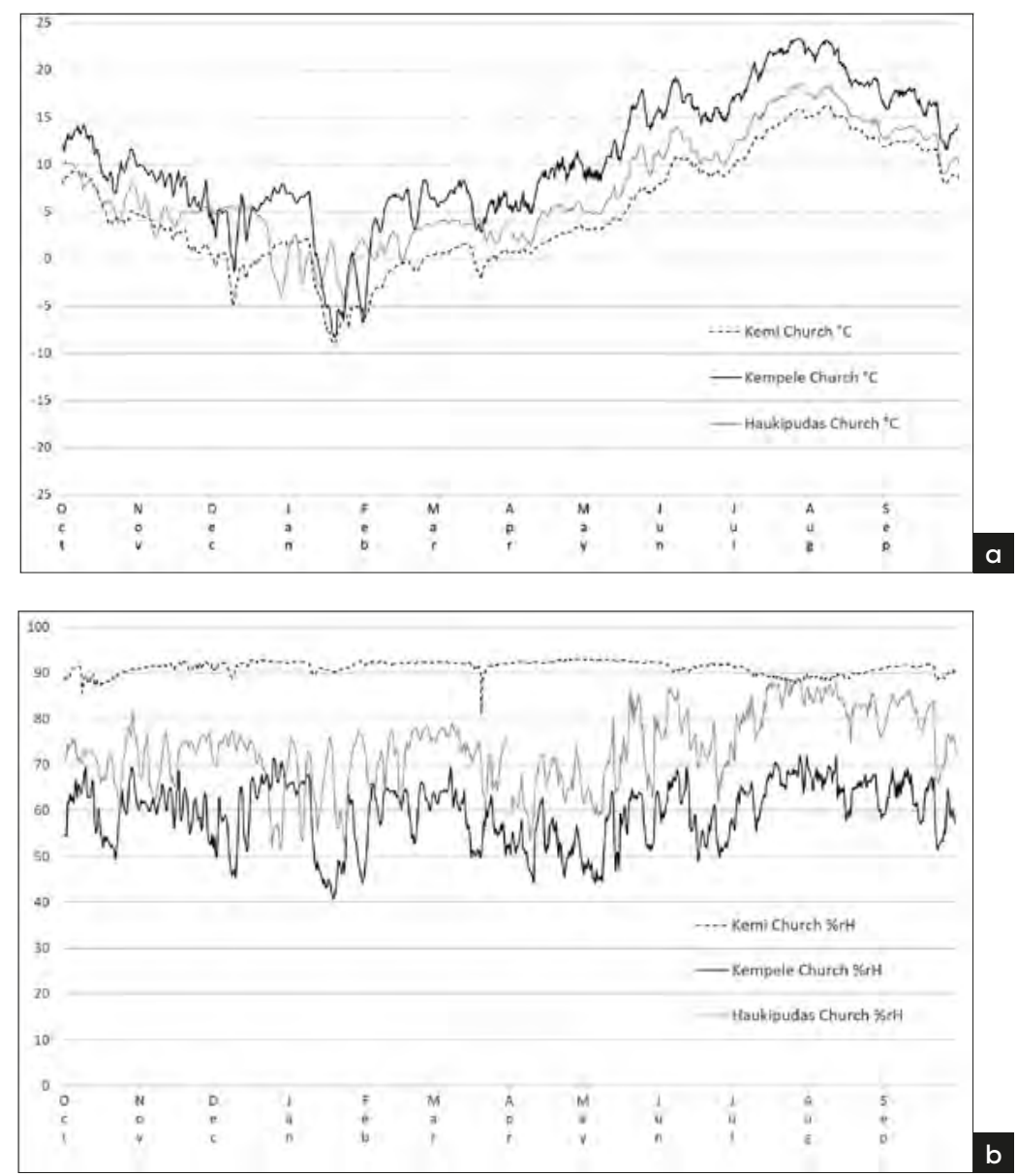

Fig. 7 (a-b). Comparison of temperature and humidity on the three churches.

Several experiments have been conducted to better understand the natural mummification process seen under church floors of northern Finland. Nurminen and colleagues (2017) performed a I09 day-long experiment in spring 2017 to study potential effects of cold air, dry sand, coffin, and burial textiles on mummification. This experiment clearly demonstrated that good ventilation, dry sand and certain textiles may have beneficial effects on mummification process. However, they also noticed that freeze drying is nothing that automatically occurs in Finnish winter. Further experiments were performed in laboratory conditions and they have confirmed the importance of constant air flow in addition to cool temperature (Nurminen et al. submitted).

The surprisingly high humidity measured beneath churches must for some reason be tolerated by the mummified remains. Relative humidity (\%rH) expresses 

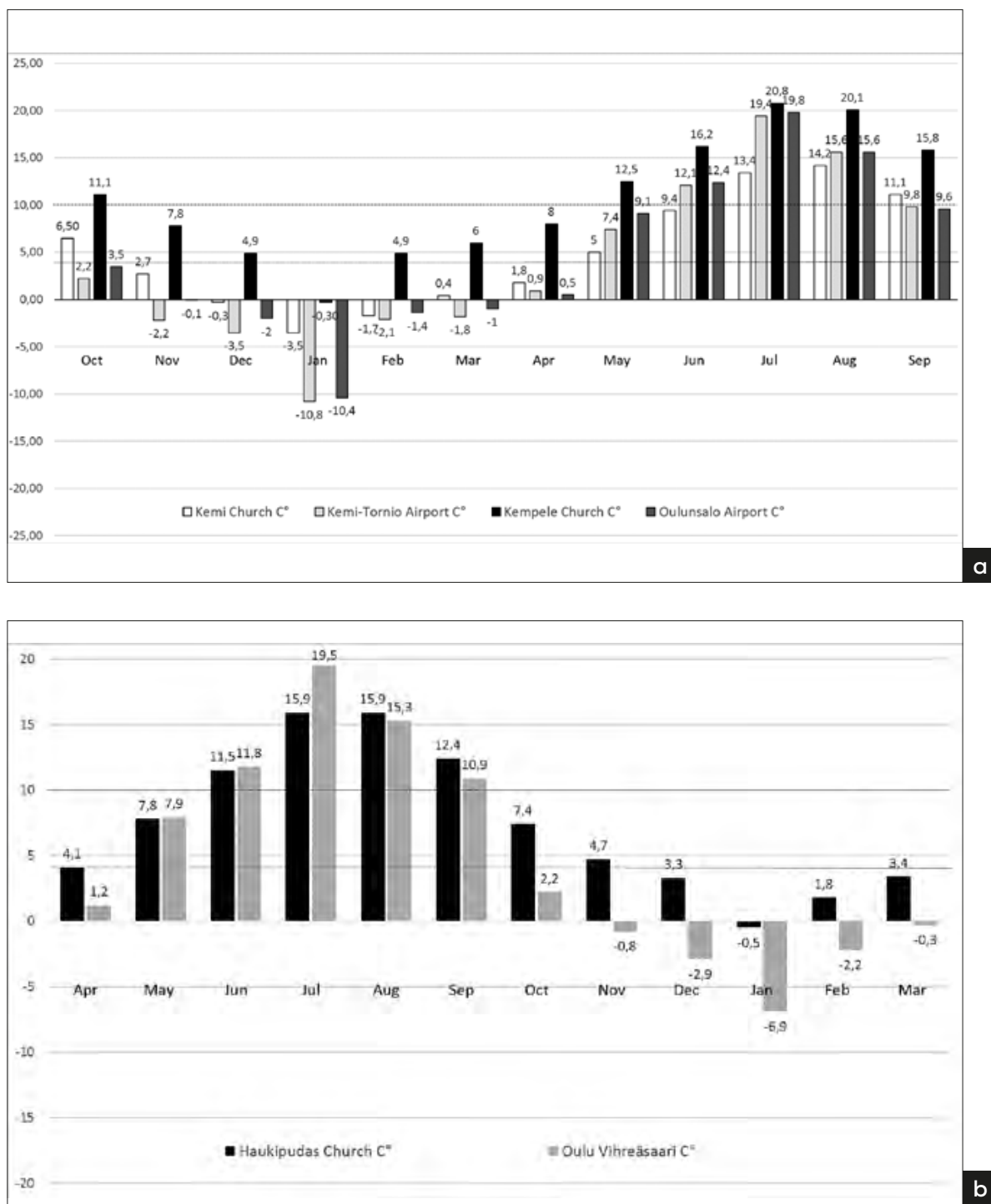

Fig. 8 (a-b). Temperatures in the base-floors of the old churches of Keminmaa and Kempele and in the church of Haukipudas in contrast to the outdoor temperatures. Note the differences in the dates.

the measure of vapor in relation the holding capacity of air at a certain temperature. Evaporation, which allows materials to dry, is not possible in 100\%rH and it slows down as relative humidity raises. Thus, drying of soft tissues is less efficient when the relative humidity is high. 


\section{Conditions inside coffins}

There are yet other factors that may have influenced the mummification process, such as the planks used to build the coffins, as unprocessed wood materials have antibacterial qualities that may have affected the process (Vainio-Kaila 2017; Lipkin et al. 2020), as well as, the funerary practices that sometimes involved long death watches (Kuusisto 1929: 78). Additionally, the circumstances surrounding the death as well as the physical qualities of the deceased or simply storing the deceased in cold, drafty environments prior to the burial probably played a role in producing mummies (Laiho 1981: 135-137, 139; Dix, Graham 2000: 13-14; Janaway et al. 2009: 329; Prahlow 2010: 175, 177).

Coffin furnishing and funerary attire may also aid mummification. Inside the coffin, the mattress material has often absorbed the liquid, which may have aided the preservation. The plants have helped to dry and, in some cases, to kill the bacteria. Plants have often been placed in the coffin - sometimes for their smell. Some of them have been used both in burials and mummification process for thousands of years. Interestingly, a great part of the identified species have antiseptic, or insect-repelling properties, and such effects were known already in the $17^{\text {th }}$ century (Lagerås 2016: 15-28; Abdel-Maksoud, El-Amin 2011: 134; Buckley, Evershed 200I). In fact, their antibacterial qualities often helped to control odour formation by inhibiting bacterial and fungal activity. Whether these plants were selected because of their antimicrobial effects or their odour, they impacted the decomposition; some of them even by absorbing body liquids or moisture from the surrounding environment, which contributed to balancing the moisture content (Kallio-Seppä, Tranberg 2020; Lipkin et al. 2020). For example, conifer sawdust - a constant long-lasting ingredient in mummification - is commonly found in early modern under-floor-burials in Swedish churches as well (Hagberg 1937). Parts of Norway spruce, birch bark, hay, mosses and herbs are the main grave plants in the research area (Tranberg 2015; Lipkin et al. 2020).

Adults provide more bodily liquids with more bacteria than newborns and infants, which may be the reason for children to be mummified more often than adults. On the other hand, in the burials with skeletonized remains, the preservation of the textiles is likely due to immersion of bodily liquids. Additionally, the preservation of the human remains and associated textiles is affected by certain in-burial-factors, such as metal artifacts, dye processes of the fabrics of funerary attire, and tar used to coat the coffin. Mold has been observed in many northern Finnish church burials as well as rodent disturbance. However, the effect of soil is the most fundamental cause for the decay of both remains and textiles (see more for the textile preservation and decay in northern Finnish burials in Lipkin et al. 2020).

Season of the burial may be revealed by examining both the state of mummification and the presence of insects. Their development stages are geographically 
and seasonally different. Temperatures, humidity, whether outdoors or indoors, and underwater influence affect the insect colonization, how fast it is and how long the various stages of flies develop. In summer conditions $\left(21^{\circ} \mathrm{C}, 30 \%\right.$ humidity), the hair of a corpse of an adult begins to fall within three days. Northern Finnish mummies often have hair. Under normal conditions, the putric phase begins within 24 hours and the bloated phase is reached in four days. Blowflies do not oviposit in dehydrated or mummified tissue. The colonization starts right after dead, firstly from the cavities and wounds. In summer conditions a body may become dry in two weeks (Prado e Castro et al. 2012: 425) and an infant may skeletonize after five days (Catts, Coff 1992: 262).

The invasion may be delayed in certain circumstances. Except for Phoridae, most of the flies cannot enter the corpse through the soil (at least $30 \mathrm{~cm}$ ) over the burial. Phoridaes can be found from buried corpses and coffins (Amendt et al.

Tab. 4. Insect species sampled from randomly chosen coffins found in Haukipudas and Keminmaa (Lipkin et al. 2020).

\begin{tabular}{|c|c|c|c|c|}
\hline Haukipudas & & & & Faunal remains \\
\hline Coffin 1 & 7-year-old & Female & Mummified & $\begin{array}{l}\text { Protophormia terraenovae; Mono- } \\
\text { pis laevigella }\end{array}$ \\
\hline Coffin 2 & Newborn & Female & Skeletonized & $\begin{array}{l}\text { Megaselia; Muscina; Fannia (sca- } \\
\text { laris); Protophormia terraenovae; } \\
\text { Anthrenus museorum }\end{array}$ \\
\hline Coffin 3 & 2 year-old & Male & Skeletonized & Calliphora; Monopis laevigella \\
\hline Coffin 4 & Mature & Male & Skeletonized & $\begin{array}{l}\text { Calliphora (Lucilia?); Heleomyzi- } \\
\text { dae (Heleomyzini, Neoleria); } \\
\text { Protophormia terraenovae }\end{array}$ \\
\hline Coffin 6 & Newborn & & $\begin{array}{l}\text { Skeletonized, } \\
\text { preserved } \\
\text { badges of skin }\end{array}$ & $\begin{array}{l}\text { Heleomyzidae (Heleomyzini, } \\
\text { Neoleria); Myodes glareolus } \\
\text { (droppings) }\end{array}$ \\
\hline Coffin 10 & Adult & Male & Skeletonized & Fannia scalaris/coracina \\
\hline Coffin 11 & Child & & Skeletonized & $\begin{array}{l}\text { Myodes glareolus (droppings); An- } \\
\text { threnus museorum; Calliphoridae }\end{array}$ \\
\hline \multicolumn{5}{|l|}{ Keminmaa } \\
\hline Coffin 10 & Infant & & Mummified & $\begin{array}{l}\text { Heleomyzidae (Heleomyzini, } \\
\text { Neoleria); }\end{array}$ \\
\hline Coffin 11 & Adult & Male & Mummified & $\begin{array}{l}\text { Heleomyzidae (Heleomyzini, } \\
\text { Neoleria); }\end{array}$ \\
\hline Rungius & Mature & Male & Mummified & \\
\hline
\end{tabular}


2004: 54). Coffin 2 in Haukipudas had among other things remains of (Phoridae) Megaselia (Lipkin et al. 2020; Tab. 4). Phoridae species tend to come to the body later and prefer older carcasses (Campobasso et al. 2004: I). Because of its small size it can enter coffin using even narrow cuts. Funerary attire may also delay the colonization.

The duration of each decomposition stage and the species may differ, but the order of taxonomic families is constant. Blowflies come first, then flesh flies and after those, for example, Fannia scalaris (Campobasso et al. 2004: 2; Catts, Coff 1992: 260, 262), which were found in some coffins at Haukipudas Church (Tab. 4). The presence of this species automatically refers to the advanced stage of putrefication and it requires warmer weather than Protophormia terraenovae and Heleomyzidae species. The presence of northern blowfly, Protophormia terraenovae, refers to moisture and shade. It arrives to corpse first, especially in northern Finland, if it is not prevented by a tightly sealed coffin (Nuorteva 1977; 1987; Smith 1986; Rognes 1991: 137).

On the other hand, presence of some species automatically implies dry or mummified body (Soszynska-Maj, Woźnica 2016), similar to Heleomyzidaes found on Keminmaa mummies (Lipkin et al. 2020). Protophormia terraenovae and Heleomiyzidae species overwinter and settle near food ready to appear in the spring. In northern Finland $P$. terraenovae is the most dominant blowfly in every season and the immature stages may overwinter also, not just adults (Nuorteva 1987: 137).

It is indeed likely that the mummification under the church-floor took place during the colder months, which is indicated by the insect remains found in connection to the burials. In coffins of the mummified individuals, no remains of insect species typical for summertime could be found, nor do any of the found ones refer to putrefaction. Insect species that are typical for colder seasons were common. Associated with mummified remains, the insect remains consisted of winter species either consuming the corpse immediately after the death (winter blowfly, Protophormia terraenovae, the most commonly occurring species in our study), or only once it has dried (Heleomyzidae) (Warren 2006; Carrion Ecology... 20I5; Soszynska-Maj, Woźnica 2016). In many cases, the findings are consistent with a burial in cold environment and subsequent drying of the tissues rather soon after the death. However, as indicated by the first stage insect activity interrupted since, some of the mummified corpses had initially been exposed to warmer environments $\left(>\sim 9^{\circ} \mathrm{C}\right.$ observed in laboratory conditions) for a considerable period prior to the cold conditions ceasing the decay process. This may either be due to the seasonal fluctuation in temperature in spring or autumn or the treatment of the deceased (Warren 2006: 79).

In the coffins containing skeletonized remains, the situation was expectedly a little different. The species of flies found in them normally refer to the warmer season and advanced putrefaction. Only in one, containing an elderly male presenting with some remnants of preserved soft tissues, remains of Heleomyzidae (Heleomyzini) 
utilizing dry tissues were found. Additionally, these coffins contained remains of latrine fly (Fannia scalaris) - a species that infest the body once the decay has progressed to liquefaction of tissues, which occurs at the late stage of putrefaction.

\section{Conclusions}

The temperature and humidity data obtained in the target churches reveals the conditions in which the mummified human remains representing our valuable cultural heritage are currently stored. The information, however, may in part also reflect those circumstances under which the mummification originally occurred during the period of under-church-floor burials. The renovations realized in the churches have altered their condition. Their effect in some churches is more pronounced than in others. The heating of the church halls in Kempele and Haukipudas is likely significant determinant of the temperature and humidity of their base-floors - even when the floor in Haukipudas is insulated. The overall climate today, however, is probably not very different from it was during the burial period. Although it coincides with the "Little Ice Age", according to the analyses of tree-rings, the period between 1660 and 1780 , during which most of the burials were made, the climate was slightly warmer and probably on average only a few degrees cooler than today.

According to the rather high humidity in each of the churches, dry environment may not be one of the main components explaining mummification in Finnish churches. We cannot be sure that the mummification took place in such cellar like conditions measured currently beneath our old churches. What is more, we have so far not managed to explain, why the rather high humidity does not seem to disturb the preservation of the mummified remains.

In the old church of Keminmaa, where the temperature is probably closest to that of the burial period, during most measurements, it remains under the point $\left(\mathrm{I} 0^{\circ} \mathrm{C}\right)$ over which decomposition accelerates. It is likely that cool winter temperatures that have also prevailed in the other churches before installing the heating systems played a major role in soft tissue preservation. This is even suggested by the division of the insect remains found near the remains preserved in varying degrees.

Both variables - temperature and humidity - exhibit different values although especially temperature in each church follows rather uniform trends. In addition to the heating the differences may be partially explained by the different base-floor structures and building materials. These differences may further imply that other factors beside humidity and temperature must have influenced the soft tissue preservation encountered underneath our old churches. Although ventilation was not monitored, we believe that steady and brisk air movement did efficiently remove moisture from the remains, and thus, was one of the main contributors to the phenomenon. In previous studies of mummification, it has been named an important factor behind preservation. 
Not only the micro-climate conditions in the base-floors of the studied churches were significant in terms of the unusual preservation observed in connection to the burials. For example, the materials used to dress the deceased as well as to furbish and even build the coffins often hosted antibacterial qualities. Some of them contributed in absorbing the liquefied remains of decomposition thus inhibiting the process. Further contributors may have been the events before burial, such as long death watches or storing in cool premises. Even the more personal qualities of the deceased may have been significant as preservation is influenced by factors such as perimortem health or body composition.

\section{Acknowledgements}

We wish to thank Senior museum technician Jere Kahanpää, Finnish Museum of Natural History, Luomus, Zoology unit, University of Helsinki and Building researcher Teija Ylimartimo, The Museum of Tornio Valley.

\section{Bibliography}

Abdel-Maksoud G., El-Amin A.-R. (20II), A Review on the Materials Used during the Mummification Processes in Ancient Egypt, "Mediterranean Archaeology and Archaeometry", II (2), p. I29-I5O.

Amendt J., Krettek R., Zehner R. (2004), Forensic Entomology, "Naturwissenschaften”, 9I, p. 5I-65, https://doi.org/IO.IOO7/sOoII4-003-0493-5

Aufderheide A.C. (2010), The Scientific Study of Mummies, Cambridge University Press, Cambridge.

Buckley S.A., Evershed R.P. (200I), Organic Chemistry of Embalming Agents in Pharaonic and Graeco-Roman Mummies, "Nature", 4I3, p. 837-84I, https://doi.org/Io.1038/35IOI588

Büntgen U., Raible C.C., Frank D., Helama S., Cunningham L., Hofer D., Nievergelt D., Verstege A., Timonen M., Stenseth N.C., Esper J. (20II), Causes and Consequences of Past and Projected Scandinavian Summer Temperatures, 500-2I00 AD, "PLoS ONE", 6 (9), p. e25I33, https://doi.org/IO.I37I/journal.pone.0025I33

Cajanus K.I. (1927), Piirteitä Kemin Maaseurakunnan Kirkkojen Historiasta, Tekijä, Tornio.

Calamnius J.W. (I868), Muinais-tiedustuksia Pohjanperiltä, "Suomi: Kirjoituksia isänmaallisista aineista”, 2 (7), p. I9I-267.

Campobasso C.P., Disney R.H.L., Introna F. (2004), A Case of Megaselia scalaris (Loew) (Dipt., Phoridae) Creeding in a Human Corpse, "Aggrawal's Internet Journal of Forensic Medicine and Toxicology", 5, p. 3-5.

Carrion Ecology, Evolution, and their Applications (2015), E.M. Benbow, J.K. Tomberlin, A.M. Tarone (ed.), crc Press, Boca Raton.

Catts E.P., Coff M.L. (I992), Forensic Entomology in Criminal Investigations, "Annual Review of Entomology", 37, p. 253-272, https://doi.org/IO.II46/annurev.en.37.0IOI92.00I345 
Dix J., Graham M. (200o), Time of Death, Decomposition and Identification. An Atlas, CRC Press LlC, Boca Raton, https://doi.org/IO.I20I/978I420048285

Eronen M., Zetterberg P., Briffa K.R., Lindholm M., Meriläinen J., Timonen M. (2002), The Supra-long Scots Pine Tree-ring Record for Finnish Lapland: Part I, Chronology Construction and Initial References, "The Holocene", I2 (6), p. 673-68o, https://doi.org/IO.II9I/0959683602hl580rp

Fiedler S., Graw M. (2003), Decomposition of Buried Corpses, with Special Reference to the Formation of Adipocere, "Naturwissenschaften", 90, p. 291-300, https://doi.org/I0.I007/sooli4-003-0437-0

Grassberger M., Frank C. (2004), Initial Study of Arthropod Succession on Pig Carrion in a Central European Urban Habitat, "Journal of Medical Entomology", 4I (3), p. 5II-523, https://doi.org/IO.I603/0022-2585-4I.3.5II

Grassberger M., Reiter C. (2002), Effect of Temperature on Development of the Forensically Important Holarctic Blow Fly Protophormia terraenovae (Robineau-Desvoidy) (Dipetra: Calliphoridae), "Forensic Science International”, I28 (3), p. I77-182, https://doi.org/IO.IOI6/So379-0738(02)oor99-8

Hagberg L. (1937), När döden gästar. Svenska folkseder och svensk folktro I samband med död och begravning, Wahlström \& Widstrand, Stockholm.

Helama S., Lindholm M., Timonen M., Eronen M., Meriläinen J. (2002), The Supra-long Scots Pine Tree-ring Record for Finnish Lapland: Part 2, Interannual to Centennial Variability in Summer Temperatures for 7500 Years, "The Holocene”, I2 (6), p. 68I-687, https://doi.org/IO.II9I/0959683602hl58Irp

Helama S., Timonen M., Lindholm M., Meriläinen J., Eronen M. (2005), Extracting Long-period Climate Fluctuations from Tree-ring Chronologies over Timescales of Centuries to Millennia, "International Journal of Climatology", 25 (13), p. 1767-1779, https://doi.org/IO.IOO2/joc.I2I5

Helama S., Timonen M., Holopainen J., Ogurtsov M.G., Mielikäinen K., Eronen M., Lindholm M., Meriläinen J. (2009), Summer Temperature Variations in Lapland During the Medieval Warm Period and the Little Ice Age Relative to Natural Instability of Thermohaline Circulation on Multi-decadal and Multi-centennial Scales, "Journal of Quaternary Science”, 24 (5), p. 450-456, https://doi.org/IO.IOo2/jqs.I29I

Hiltunen M. (1982), Kempeleen historia, Kempeleen kunta ja seurakunta, Oulu.

Itkonen T. (1976), Keminmaan kirkkojen vaiheilta, T. Itkonen, Kemi.

Janaway R.D., Percival S.L., Wilson A.S. (2009), Decomposition of Human Remains, [in:] S.L. Percival (ed.), Microbiology and Aging. Clinical Manifestations, Springer, Flintshire, p. 313-334, https://doi.org/IO.I007/978-I-59745-327-I_I4

Joona J.-P., Ojanlatva E. (1997a), Keminmaan kirkon kuoriosan hautakammiot ja hautaukset, [in:] E. Ojanlatva, K. Paavola (ed.), Keminmaan kirkkohaudat. Meteli I4, University of Oulu, Oulu, p. 32.

Joona J.-P., Ojanlatva E. (I997b), Keminmaan kirkon kuorin ja keskiosan luulöydöt, [in:] E. Ojanlatva, K. Paavola (ed.), Keminmaan kirkkohaudat. Meteli I4, University of Oulu, Oulu, p. 6-I6.

Joona J.-P., Ojanlatva E., Paavola K., Pöppönen S., Tikkala E., Tuovinen O., Alakärppä J. (1997), Kempeleen kirkkohaudat, University of Oulu, Oulu. 
Kallinen M. (1990), Legendoja ja käsityksiä Rungiuksesta kansan suussa ja politiikan välineenä, "Jatuli", 2I, p. I24-I36.

Kallio-Seppä T., Tranberg A. (2020), The Materiality of Odors: Experiencing Church Burials and the Urban Environment in Early Modern Northern Sweden, "Historical Archaeology" (forthcoming), https://doi.org/IO.I007/s41636-020-00264-2

Kangasvuo J., Pöppönen S. (1997), Keminmaan kirkon toisen ja kolmannen niskahirren väliset multahaudat, [in:] E. Ojanlatva, K. Paavola (ed.), Keminmaan kirkkohaudat. Meteli I4, University of Oulu, Oulu, p. I7-I9.

Koivunen P. (1997), Keskiaika ja I5oo-luku. Kristinuskon vaikutus, [in:] R. Satokangas (ed.), Keminmaan historia, Jyväskylä, p. 4I-5I.

Koskela T. (1997), Haukiputaan kirkkohautojen dokumentointia ja kirkon historiaa, [in:] J. Alakärppä, K. Paavola (ed.), Haukiputaan kirkkohaudat. Meteli I3, University of Oulu, Oulu, p. 7-I2.

Kuusisto P.A. (1929), Hautausmaista ja kirkkoon hautaamisesta Porin kaupungissa ja maaseurakunnassa I700-I800-luvuilla, Turun yliopiston ylioppilaskunta, Turun ylioppilas I, Tyrvään kirjapaino OY, Vammala, p. 72-86.

Lagerås P. (2016), Från trädgård till grav: växterna i biskop Peder Winstrups kista, "Ale", 4 , p. $15-28$.

Laiho K. (198I), Patologinen ja kriminalistinen oikeuslääketiede III. Kuoleman jälkeiset muutokset, [in:] J. Raekallio, A. Alha, J. Hirvonen, M. Möttönen (ed.), Oikeuslääketiede, Porvoo, p. 132-I39.

Lipkin S., Väre T., Kallio-Seppä T. (2018), Pappissäädyn haudat Pohjois-Pohjanmaan kirkkojen lattioiden alla - Tapaustutkimuksia I300-I700-luvuilta, "Thanatos”, 7, p. 60-88.

Lipkin S., Ruhl E., Vajanto K., Tranberg A., Suomela J. (2020), Textiles: Decay and Preservation in the $17^{\text {th }}-19^{\text {th }}$ Century Burials in Finland, [in:] T. Kallio-Seppä, S. Lipkin, P.R. Mullins (ed.), Historical Burials in Europe. Natural Mummification, Burial Customs, and Ethical Challenges, "Historical Archaeology", 54, 4.

Marjomaa M., Ruonakoski A. (1997), Keminmaan kirkon länsiosan multahaudat, [in:] E. Ojanlatva, K. Paavola (ed.), Keminmaan kirkkohaudat. Meteli I4, University of Oulu, Oulu, p. 27-31.

Mielikäinen K., Timonen M., Helama S. (2012), Ilmastonmuutokset ja niiden syyt puulustojen ja muiden proksitietojen pohjalta, [in:] A. Asikainen, H. Ilvesniemi, R. Sievänen, E. Vapaavuori, T. Muhonen (ed.), Bioenergia, ilmastonmuutos ja Suomen metsät, Finnish Forest Research Institute, Vantaa (Working Papers of the Finnish Forest Research Institute, 240), p. 32-52.

Nuorteva P. (1977), Sarcosaprophagous Insects and Forensic Indicators, [in:] C.G. Tedeschi, W.G. Eckert, L.G. Tedeschi (ed.), Forensic Medicine. A Study in Trauma and Environmental Hazards, vol. II, Saunders, Philadelphia-London-Toronto, p. I072-I095.

Nuorteva P. (1987), Empty Puparia of Phormia terraenovae R.-D. (Diptera, Calliphoridae) as Forensic Indicators, "Suomen hyönt. Aikak", 53, p. 53-56.

Núñez M., Paavola K., García-Guixe E. (2008), Mummies in Northern Finland, [in:] P. Atoche Peña, C. Rodgues Martin, M. Ángeles Ramírez Rodríquez (ed.), Mummies and Science, World Mummies Research, Proceedings of the VI World Congress on Mummy Studies, Teguise, Lanzarote, p. I23-I28. 
Nurminen N., Niskanen M., Ahonen S., Junno J.A., Kuha A., Marjakangas S., Natural Mummification in Cool Temperatures in Northern Finland: Incubator Chamber Experiment, "The Journal of Nordic Archaeological Science (JONAS)" (submitted).

Nurminen N., Lipkin S., Kuha A., Väre T., Marjakangas S., Niskanen M., Junno J.-A. (2017), Experimental Mummification in Northern Finland, "Fennoscandia Archaeologica", 34, p. I46-I5I.

Ojanlatva E. (1997), Haukiputaan kirkkohautojen dokumentointia ja kirkon historiaa, [in:] J. Alakärppä, K. Paavola (ed.), Haukiputaan kirkkohaudat. Meteli I3, University of Oulu, Oulu, p. I-6.

Paavola K. (1997), Keminmaan vanhan kirkon hautojen tutkimus, [in:] E. Ojanlatva, K. Paavola (ed.), Keminmaan kirkkohaudat. Meteli I4, University of Oulu, Oulu, p. I-4.

Paavola K. (1998), Kepeät mullat. Kirjallisiin ja esineellisiin lähteisiin perustuva tutkimus Pohjois-Pohjanmaan rannikon kirkkohaudoista, Oulun yliopisto, Oulu (Acta Universitatis Ouluensis. Series B, Humaniora, 28).

Paavola K. (2009), Hautaamatta haudatut, [in:] J. Ikäheimo, S. Lipponen (ed.), Ei kiveäkään kääntämättä-Jublakirja Pentti Koivuselle, Tornio, p. 24I-250.

Paavola K. (20I2), Haukiputaan kirkkohautojen ongelmalähteet, [in:] S. Niinimäki, A.-K. Salmi, J.-M. Kuusela, J. Okkonen (ed.), Stones Bones \& Thoughts. Festschrift in Honour of Milton Núnez, Oulu, p. IOI-III.

Pernter P., Gostner P., Egarte-Vigl E., Rühli F.J. (2007), Radiologic Prooffor the Iceman's Cause of Death (ca. 5'300 BP), "Journal of Archaeological Science", 34 (II), p. 1784-1786, https://doi.org/IO.IOI6/j.jas.2006.I2.0I9

Pettersson L., Hyvönen H. (199I), Kempeleen kirkko, Museoverasto, Helsinki (Suomen kirkot, I7).

Prado e Castro P., Serrano A., Martins da da Silva P., Garcia M.-D. (2012), Carrion Flies of Forensic Interest: a Study of Seasonal Community Composition and Succession in Lisbon, Portugal, "Medical and Veterinary Entomology", 26 (4), p. 36I-469, https://doi.org/IO.IIII/j.I365-2915.2012.0I031.x

Prahlow J.A. (2010), Forensic Pathology for Police, Death Investigators, Attorneys, and Forensic Scientists, Humana Press, New York, https://doi.org/I0.I007/978-I-59745-404-9

Quigley C. (2006), Modern Mummies. The Preservation of the Human Body in the Twentieth Century, McFarland Company, Inc., Publishers, Jeffersson.

Raappana T. (2017), pers.com. 13.3.2017 verger of the Kempele parish, Tapani Raappana.

Rognes K. (1991), Blowflies (Diptera, Calliphoridae) of Fennoscandia and Denmark, Brill, Leiden.

Rudenko S.I. (1970), Frozen Tombs of Siberia. The Pazyryk Burials of Iron Age Horsemen, University of California Press, Berkeley.

Satokangas R. (1997), Murroksen aika (I860-1930), [in:] R. Satokangas (ed.), Keminmaan historia, Jyväskylä, p. 250-442.

Smith K. (1986), A Manual of Forensic Entomology, British Museum (Natural History) and Cornell University Press, London.

Soszynska-Maj A., Woźnica A.J. (2016), A Case Study of Heleomyzidae (Diptera) Recorded on Snow in Poland with a Review of their Winter Activity in Europe, "European Journal of Entomology”, II3, p. 279-294, https://doi.org/Io.I44II/eje.2016.035 
Tikkala E. (1997), Keminmaan kirkon kolmannen ja neljännen niskahirren väliset multahaudat, [in:] E. Ojanlatva, K. Paavola (ed.), Keminmaan kirkkohaudat. Meteli I4, University of Oulu, Oulu, p. 20-26.

Tranberg A. (2015), Burial Customs in the Northern Ostrobothnian Region (Finland) from the Late Medieval Period to the $20^{\text {th }}$ Century. Plant Remains in Graves, [in:] S. Tarlow (ed.), The Archaeology of Death in Post-medieval Europe, De Gryuter, Warsaw, p. I89-203, https://doi.org/IO.I515/978311043973I-OIO

Vahtola J. (1980), Haukiputaan seurakunnan historia, Haukiputaan seurakunta, Haukipudas.

Vainio-Kaila T. (20I7), Antibacterial Properties of Scots Pine and Norway Spruce (Doctoral dissertation, Aalto University publication series Doctoral dissertations, I79/2017).

Väre T., Heino M., Junno J.-A., Lipkin S., Niinimäki J., Niinimäki S., Niskanen M., Núńez M., Tranberg A., Tuovinen S., Vilkama R., Ylimaunu T., Kallio-Seppä T. (20I4), Kempeleen ja Keminmaan vanhojen kirkkojen muumiot, "Muinaistutkija", I, p. I7-32.

Warren J.-A. (2006), The Development of Protophormia Terraenovae (Robineau-Desvoidy) (Diptera: Calliphoridae) at Constant and Fluctuating Temperatures (Doctoral dissertation, Simon Fraser University, Canada).

Wilson A., Taylor T., Ceruti M.C., Chávez J.A., Reinhard J., Grimes V., Meier-Augenstein W., Cartmell L., Stern B., Richards M., Worobey M., Barnes I., Gilbert T. (2007), Stable Isotope and DNA Evidence for Ritual Sequences in Inca Child Sacrifice, "PNAS (Proceedings of the National Academy of Sciences of the USA)", IO4 (42), p. I6456-I646I, https://doi.org/I0.I073/pnas.0704276IO4

Zimmerman M.R. (1996), Mummies of the Arctic Regions, [in:] K. Spindler, H. Wilfing, E. Rastbichler-Zissernig, D. zur Nedden, H. Nothdurfter (ed.), Human mummies. A Global Survey of their Status and the Techniques of Conservation, Springer, Vienna (The Man in the Ice, 3), p. 83-92, https://doi.org/Io.I007/978-3-709I-6565-2_9

Zimmerman M.R., Smith G.S. (1975), A Probable Case of Accidental Inhumation of 1,600 Years Ago, "Bulletin of the New York Academy of Medicine", 51, p. 828-837.

\section{Summary}

Temperature and Humidity in the Base-floors of Three Northern Finnish Churches Containing $17^{\text {th }}-19^{\text {th }}$-century Burials

Natural mummification occurs in various favorable conditions. Cold environments have produced mummified human remains in northern Finland. These remains buried under the church floors mummified naturally probably through a process resembling freeze-drying. This chapter explores the conditions that led to the mummification of dozens and potentially hundreds of human remains. To conduct our study, we installed logging temperature and humidity measuring devices under the floors of three churches located by the shore of Bothnian Bay in northern Finland. Even our preliminary results show that the humidity and temperature conditions differ between these churches. It is also clear that relative humidity remains very high under the floors of each church. It appears 
that mummification has occurred in almost "cellar like" conditions. The preservation process was probably aided by the loose laid constructions allowing the air to freely move in the graves carrying the moisture from the remains.

Keywords: Early modern, Church archaeology, mummification, Finland

\section{Streszczenie}

Temperatura i wilgotność w podziemiach trzech kościołów na północy Finlandii, zawierających pochówki z okresu od XVII do XIX w.

Do mumifikacji naturalnej dochodzi pod wpływem różnego rodzaju korzystnych warunków. W północnej Finlandii szczątki zostały zmumifikowane w chłodnym środowisku. Szczątki te, pochowane pod posadzką kościołów, zostały naturalnie zmumifikowane prawdopodobnie w procesie przypominającym liofilizację. Niniejszy tekst analizuje warunki, które doprowadziły do mumifikacji dziesiątek, a być może setek szczątków ludzkich. Na potrzeby badania pod posadzkami trzech kościołów na wybrzeżu Zatoki Botnickiej w północnej Finlandii zainstalowaliśmy urządzenia pomiarowe rejestrujące temperaturę i wilgotność. Już wstępne wyniki naszych badań wskazują, że wilgotność i temperatura różnią się w zależności od kościoła. Wyraźnie też widać, że wilgotność względna pod posadzką każdego z kościołów pozostaje bardzo wysoka. Wygląda na to, że do mumifikacji doszło w niemal piwnicznych warunkach. Proces konserwacji prawdopodobnie ułatwiły luźno rozmieszczone struktury, które umożliwiły swobodny przepływ powietrza w grobach, odprowadzając wilgoć.

Słowa kluczowe: wczesna era nowożytna, archeologia kościelna, mumifikacja, Finlandia

Tiina Väre

University of Oulu

Faculty of Humanities

Archaeology

Finland

e-mail: tiina.vare@oulu.fi

\section{Annemari Tranberg}

University of Oulu

Faculty of Humanities

Archaeology

Finland

e-mail: tranbergannemari@hotmail.com

\section{Sanna Lipkin}

University of Oulu

Faculty of Humanities

Archaeology

Finland

e-mail: sanna.lipkin@oulu.fi 
Temperature and Humidity in the Base-floors of Three Northern Finnish Churches...

\section{Titta Kallio-Seppä}

Tornedalens museum

Finland

e-mail: titta.kallio-seppa@tornio.fi

\section{Lauri Väre}

University of Helsinki

Faculty of Science

Computer Science

Finland

e-mail: lauri.vare@helsinki.fi

\section{Juho-Antti Junno}

University of Oulu

Faculty of Humanities

Archaeology

\&

University of Oulu

Faculty of Medicine

Medical Research Center Oulu

Finland

e-mail: juho-antti.junno@oulu.fi

\section{Sirpa Niinimäki}

University of Oulu

Faculty of Humanities

Archaeology

Finland

e-mail: sirpa.niinimäki@oulu.fi

\section{Nora Nurminen}

University of Oulu

Faculty of Humanities

Archaeology

Finland

e-mail: nora.nurminen@student.oulu.fi

\section{Anniina Kuha}

University of Oulu

Faculty of Humanities

Archaeology

\&

University of Oulu

Faculty of Science

Biology

Finland

e-mail: anniina.kuha@student.oulu.fi 